„Bohemistyka” 2019, nr 3, ISSN 1642-9893

Agata FIRLEJ

DOI: 10.14746/bo.2019.3.5

Uniwersytet im. Adama Mickiewicza

\title{
Polityka picia.
}

\section{Kilka przypadków z powojennego czeskiego teatru}

Keywords: Czech drama, Czech theatre, feast, alcohol, revolution, politics

Słowa kluczowe: czeski dramat, czeski teatr, święto, alkohol, rewolucja, polityka

\section{Abstract}

The sketch is devoted to five post-war Czech theatrical plays in which the motifs of the feast and alcohol are the signs of belonging or not belonging to the specified community and in most cases intertwine with the theme of politics: Audience of V. Havel, Švejkův vnuk of L. Balák, Nože a růže aneb topless party of M. Urban, Růže pro Marketu of M. Viewegh and Nahniličko of I. Kraus. The analysis is based mainly on the antropological models of feast offered by Michael Dietler, Brian Hayden and Claude Grignon, but their model of 'diacritic feast' is modified for the needs of the sketch. In the above mentioned dramas, the way of feasting and the favourite type of alcohol indicates the position of the character as the 'stranger' (like in Audience. Švejkưv vnuk) or the 'ruler', 'leader' (Nože a růže anebo topless party). Drinking alcohol provides also a specific dramatic rhythm. Additionaly in Viewegh's and Kraus' play the state of intoxication metaphorizes the "abnormal" period of velvet revolution or the transformation. The ritual of feasting organizes the scenery, rhythm and movement of characters, activating a number of cultural associations. The gradual "opening" of the characters, caused by changes in their consciousness, reveals inner motivation, unmask the superficiality of the bond, conduct a parallel between the individual and the collective imagery.

Szkic poświęcony jest pięciu powojennym czeskim sztukom teatralnym, w których motywy uczty i alkoholu sa przejawami przynależności do określonej społeczności, a w większości przypadków przeplatają się z tematem polityki: Audience V. Havla, Švejkưv vnuk L. Baláka, Nože a rǔže aneb topless party M. Urbana, Růže pro Marketu M. Viewegha i Nahniličko I. Krausa. Analiza opiera się głównie na antropologicznych modelach uczty opisanych przez Michaela Dietlera, Briana Haydena i Claude'a Grignona, przy czym ich model „święta diakrytycznego” został zmodyfikowany na potrzeby szkicu. We wspomnianych dramatach sposób ucztowania i ulubiony rodzaj alkoholu wskazuje pozycję bohatera jako „nieznajomego” (jak np. w dramatach Audience czy Švejkův vnuk) lub ,, władcy”, ,lidera” (jak np. w Nože a rü- 
že anebo topless party). Picie alkoholu zapewnia również specyficzny dramatyczny rytm. Dodatkowo w sztuce Viewegha i Krausa stan odurzenia metaforyzuje ,nienormalny" okres aksamitnej rewolucji lub transformacji. Rytuał biesiadowania organizuje scenerie, rytm i ruch postaci, aktywując szereg stowarzyszeń kulturalnych. Stopniowe „otwieranie się" bohaterów, spowodowane zmianami w ich świadomości, ujawnia wewnętrzną motywację, demaskuje powierzchowność więzi między nimi, ukazuje paralelę między indywidualnym a zbiorowym wyobrażeniem.

W jednej ze scen z Bękartów wojny Quentina Tarantino amerykański szpieg zamawia w barze szkocką, podnosząc palce wskazujący, środkowy i serdeczny - ten gest go dekonspiruje: Niemcy w analogicznej sytuacji dają znak kciukiem, wskazującym i środkowym. Niedocenienie znajomości biesiadnej etykiety - nawet jeśli wymyślonej na użytek popkulturowego dzieła - będzie miało dla bohaterów filmu fatalne skutki. Budując tę scenę, Tarantino korzysta ze wzorców utrwalonych w kulturze - nie tylko śródziemnomorskiej - od niepamiętnych czasów. Uczta, biesiada, sympozjon, impreza, biba (ostatnie określenie brzmi mało szlachetnie, ale warto pamiętać o jego łacińskim źródłosłowie) - ten rodzaj społecznej aktywności konsoliduje wspólnotę i stanowi jej probierz, podobnie jak udział w rytuale, dotrzymywanie zasad savoir-vivre 'u czy znajomość szeroko rozumianej mitologii. Fenomen „wspólnego picia” podlega rozmaitym typologiom; najbardziej uniwersalne - $\mathrm{i} \mathrm{w}$ wielu miejscach zbieżne - zaproponowali Michael Dietler i Brian Hayden, autorzy modelu antropologicznego określanego jako ,polityka biesiadna” (commensal politics), zbudowanego w oparciu o badania nad społecznościami Afryki i Maghrebu, oraz Claude Grignon w odniesieniu do współczesnego francuskiego obyczaju. Przytoczone badania dotycza wprawdzie konkretnych zjawisk, umiejscowionych w czasie, ale ich wnioski można rozciagnać na inne praktyki biesiadne, włącznie z czeskimi, które interesują mnie szczególnie w niniejszym artykule: zamierzam w nim pokazać na kilku przykładach, jak funkcjonuje alkohol we współczesnym (powojennym) czeskim teatrze. Przyjrzę się bliżej takim sytuacjom, w których wspólne picie staje się określoną deklaracją światopoglądową, a znajomość biesiadnego kodu stanowi narzędzie wpisy- wania się do określonej grupy lub przeciwnie - demaskowania współbiesiadnika jako „obcego”.

Michael Dietler i Brian Hayden (2001) sklasyfikowali trzy główne typy uczt (pośród których wyodrębniali jeszcze dodatkowe podtypy i „,modalności”): „kooperacyjne” (alliance and cooperation feasts), „ekonomiczne” (economic feasts) i - w kontekście niniejszego artykułu najistotniejsze - „diakrytyczne” (diacritical feasts, thumaczone także jako „dystynktywne” przez polskiego badacza, Marka Węcowskiego, 2011, s. 24-28). Pierwszy rodzaj biesiady, charakterystyczny dla egalitarnej społeczności, ma na celu skonsolidowanie grupy i wzmocnienie więzi pomiędzy jej członkami; drugi typ - „ekonomiczny" - świadczy raczej o hierarchiczności w obrębie wspólnoty, ma na celu umocnienie roli lidera (wydającego ucztę) i ustabilizowanie podziału ról w grupie; podczas spotkania o charakterze ,dystynktywnym”/,diakrytycznym” dochodzi z kolei do wykluczenia „obcego" (,innego") i podkreślenia różnicy między uczestnikami biesiady a tymi, którzy nie mogą brać w niej udziału. Claude Grignon, rozważając szczegółowo różne rodzaje spotkań towarzyskich, wyodrębnił dwa najważniejsze typy ucztowania: „segregacyjne” (segregative commensality) i „transgresyjne” (transgressive commensality; zob. Grignon 2001).

Definicja pierwszego z przytoczonych typów właściwie jest zbieżna z koncepcją ,uczty diakrytycznej” Dietlera i Haydena; charakter „transgresyjny” spotkania towarzyskiego odwrotnie - oznacza, że na mocy określonego rytuału różnice zostają (chwilowo) zapomniane, przepaście zasypane, „obcy” przestają być obcymi i zostają dopuszczeni do biesiady. Oczywiście takie ujęcie - charakterystyczne dla karnawału - ma swój wymiar dialektyczny: różnice i przepaście nadal istnieją i stanowia ważny punkt odniesienia; bez nich karnawałowe przekroczenie nie byłoby możliwe. Konwencja, dobrze znana uczestnikom tego rodzaju „gry”, oznacza również, że odwrócenie ma charakter tymczasowy, jest chwilowym zawieszeniem pewnej obowiązującej normy. Paradoksalnie więc uczta transgresyjna może wzmacniać motywację selekcyjną członków „rzeczywistej” grupy. 
Klasyfikację biesiadowania rozciągniemy - w odniesieniu do nowoczesnego (czyli już po Odrodzeniu Narodowym) społeczeństwa czeskiego - na etykietę związaną z piciem piwa i, szerzej, z wyborem trunku. Skojarzenie poczucia tożsamości narodowej Czechów z upodobaniem do piwa to truizm wśród bohemistów; można tu przywołać słowa praskiego socjologa i językoznawcy z Uniwersytetu Karola Jiřego Krausa:

Vždyt' právě 19. století se svou snahou probojovat češtinu jako jazyk literární a veřejný považovalo hospodu a pití piva jako nápoje národního za významné prostředí národního uvědomění (cyt. za: Pivo a česká kultura ... 2017).

Brneński badacz obyczajów biesiadnych, Karel Altman, pisał zaś o znaczącym przeświadczeniu bywalców praskich i brneńskich gospód końca XIX wieku:

[...] pije li Čech, má vždy ruku otevřenou ke konání dobročinných skutků, hlavně skutků vlasteneckých (Altman 1993, s. 58)

Biesiadowanie ,vlastenců”, czyli czeskich patriotów, od początku miało charakter diakrytyczny/selekcyjny, było czymś w rodzaju sprawowania rytuału, uczestnicy spotkania zaś odgrywali - toutes proportions gardées - rolę kapłanów narodowej religii. W 1880 roku jednym z najskuteczniejszych inicjatorów zbiórki pieniędzy na powstanie Teatru Narodowego (Národního divadla) był Plzeňský Prazdroj. Powiązanie czeskiej kultury i poczucia tożsamości narodowej splotło się zatem na przełomie XIX/XX wieku - w okresie rozkwitu gospód $\mathrm{z}$ piciem piwa, a związek ten wydatnie wzmocniła bohema artystyczna początku XX wieku. Bohumil Hrabal, który notabene kazał się pochować w dębowej skrzyni z napisem „Pivovar Polná”, uważał się za spadkobiercę Jaroslava Haška nie tylko ze względu na jego twórczość literacką, ale i w związku z upodobaniem do gospód; na drugiego patrona wybrał Franza Kafkę, proponujac przy okazji oryginalny podział: Haszek versus Kafka, gospoda versus kawiarnia, ,chłopski rozum" versus intelekt, odpowiadający poniekąd podziałowi na nurt apolliński i dionizyjski w kulturze:
Radeji sám sebe považuji za pivního neotesance, než za osvětového intelektuála. Jsem tedy dědic tradic Jaroslava Haška. Ovšem současně se považuji za žáka Franze Kafky, který mne ohromuje svým vzděláním k transcendentnu. Myslím, že styl mého psaní je rytmizace těchto dvou světů, které tvoří základ pražské ironie. Ohromující na těchto dvou mužích je, že ač se oba narodili i umřeli toho samého roku, žili většinou v Praze, nikdy se nemohli potkat, protože Hašek procházel pražskými pivnicemi v př́zemí, a Kafka se svými přáteli kavárnami, které bývaly v prvním patře (cyt. za: Dörflová, Dyková 2009, s. 11).

Trwałość połączenia czeska kultura-piwo potwierdzają dane statystyczne. Zlecone w 2007 roku przez Plzeňský Prazdroj badania AISA (czeskiego odpowiednika OBOP-u) wykazały, że ponad 90\% badanych Czechów uznaje piwo za istotną część narodowej kultury. Znamienne, że istotniejsza dla nich jest sama „,kultura picia piwa”, czyli towarzysząca biesiadowaniu etykieta, niż samo spożycie alkoholu. Powołano nawet program dla tzw. znawców i misjonarzy piwa (,„pivní ználce a pivní misionáře”), z którymi konsultuje się narzędzia piwnego rytuału (to określenie wydaje się tu najbardziej adekwatne), poczynajac od kształtu kufli i butelek, kończac na wystroju ,wzorcowych” gospód. W ciągu dekady poprzedzającej przytoczone badania statystyczne liczba gospód w Czechach wzrosła o 75\% (trzeba jednak pamiętać, że to jest czas przemian ustrojowych), co dało ok. 35 tysięcy nowych przybytków; oczywiście wiele z nich okazało się tylko efemerydami, w dobie transformacji gospody i kawiarnie błyskawicznie upadały, w tym samym czasie powstawały jednak nowe. Ilość wypijanego piwa w Czechach wynosi od 30 lat mniej więcej 160 litrów na obywatela rocznie.

Tak istotny składnik czeskiej tożsamości musiał zatem przeniknąć do dramaturgii i teatru. Prezentowane powojenne sztuki teatralne łączy nie tylko wątek biesiadowania, najczęściej rodzaju diakrytycznego/selektywnego, jeśli odwołać się ponownie do klasyfikacji przedstawionej we wstępie do niniejszego artykułu, ale i powiązanie go z ideologią i życiem społecznym.

\section{Audience Václava Havla}

Audience (w przekładzie Sławomira Jagodzińskiego Audiencja) Havla to pierwsza z serii tak zwanych ,Vaňkovek" (od nazwiska głów- 
nego bohatera), napisana w 1975 roku, zaraz po tym, jak dramaturg z przyczyn politycznych trafił jako fizyczny pracownik do browaru w Trutnovie.

W 2009 roku powstał o tym okresie życia Havla dokumentalny film Občan Havel přikuluje ze znamiennym podtytułem Akční film o lásce k pivu, w którym pojawia się deklaracja ze strony pierwowzoru Browarnika: ,wina nie mógłbym pić, ja piję tylko piwo”. W tej jednoaktówce sposób picia - i niepicia - piwa właściwie zastepuje charakterystykę bohaterów i jest sposobem na pokazanie przepaści, jaka ich dzieli. Browarnik to awansowany człowiek z ludu, ,swój chłop”, konkretny, mocny, nie zaprzątający sobie głowy niepotrzebnymi rozterkami, lekceważący „mięczaków” i inteligentów. Waniek to właściwie „mięczak” i inteligent: delikatny, z zasadami, spięty, uporczywie nie przechodzący na „ty”, mimo że Browarnik dość szybko zaczyna mówić mu po imieniu - i przede wszystkim demaskujacy się już w pierwszych sekundach sztuki właśnie poprzez sposób picia piwa: sączy je jak wino, w duchu apollińskim, by wygłosić zdanie, które w uszach Browarnika musi brzmieć jak herezja: „nie jestem przyzwyczajony do piwa”. W kontekście powiązania piwa i czeskiej tożsamości to zdanie brzmi przecież także jak deklaracja postawy antynarodowej: Waniek, mówiąc to, po prostu sam eliminuje się z narodowej wspólnoty Czechów-piwoszy. A ponieważ jest obcy, budzi podejrzenia o nieszczerość, niechęć, może nawet poczucie wyższości (jest przecież inteligentem, więc pobudza kompleksy człowieka z ludu)

SLÁDEK U tebe člověk nikdá neví, na čem je - mlčíš - bůhví, co si myslíš - říkáš jen ,ano, pane Sládku”, ,děkuji, pane Sládku”-

VANĚK Jsem tak vychovaný -

SLÁDEK Zatímco já jsem jen nevychovanej pivovarskej buran! Myslels to tak, že jo? Neř́ikej, žes to tak nemyslel. (Havel 2019, s. 12)

${ }^{1}$ „Browarnik - Z tobą człowiek nigdy nie wie, jak to jest - milczysz, choler wie co sobie myślisz - mówisz tylko „tak, panie kierowniku”, „dziękuję panie kierowniku".

Waniek - Tak jestem wychowany.

Browarnik - Za to ja jestem niewychowany cham $\mathrm{z}$ browaru! Tak myślałeś, nie? Nie gadaj, że tak nie pomyślałeś" (Havel 1991, s. 22).
Centralnym punktem scenografii jest stół i powiększająca się bateria butelek po piwie. Dwaj bohaterowie, mówiąc skrótowo, siedzą, piją i rozmawiają. Nalewanie, wychylanie i sięganie po nową butelkę nadaje rytm upływającemu czasowi, wychodzenie do toalety odmierza jeszcze bardziej wyraziście kolejne cześci tej jednoaktówki, pozwala zaznaczyć proces, jaki zachodzi w samym Wańku. Taka rytmizacja jest charakterystycznym chwytem w teatrze absurdu - postaci sa jak gdyby zmechanizowane, funkcjonują jak manekiny czy kukiełki pociągane za niewidzialne sznurki, jak na przykład w Łysej śpiewaczce Eugéne'a Ioneski. W ten sposób manifestuje się $\mathrm{w}$ tym teatrze obecność systemu, czegoś, co przerasta pokazywaną sytuację i jednocześnie silnie na nią wpływa, steruje nią. Właśnie o systemie mówi przecież Waniek w finale sztuki, kiedy po wychyleniu paroma haustami kufla piwa - co wcześniej było dla niego niewykonalne - oświadcza: „wszystko jest do dupy” (,všechno je na hovno”). Rytuał wspólnego picia ma więc tu wymiar ściśle dramaturgiczny: organizuje scenerię, rytm i ruch postaci, uruchamiając szereg kulturowych (biesiadnych) skojarzeń, tyle tylko, że to nie jest biesiada dwóch przyjaciół, to jest rodzaj gry - bliskiej transgresyjnemu typowi uczty, podszytej silnym diakrytycznym podziałem - w której może zwyciężyć tylko jedna strona. Scenografia Audiencji, dodajmy, zorganizowana jest w sposób bardzo precyzyjny. W pierwszych didaskaliach Havel zaznacza, że na ścianie ma wisieć obraz przedstawiający Szwejka i Palivca, z podpisem: „Gdzie się piwo warzy, tam się dobrze darzy”. Szwejk jest tutaj symbolem ambiwalentnym: $z$ jednej strony mamy odwołanie do stereotypu Czecha-wesołego piwosza, z drugiej: Szwejk to także brat rodzony Józefa K. z Procesu, patron dysydenta-Havla, który wydobywa absurd systemu, biorąc na warsztat jedną tylko sytuację, w której Browarnik prosi Wańka, żeby donosił sam na siebie.

\section{Švejkův vnuk Luboša Baláka}

Bohater powieści Jaroslava Haška jest również patronem satyry politycznej Luboša Baláka Švejkův vnuk, napisanej w roku 2001. Ak- 
cja rozgrywa się przez większość czasu albo w gospodzie Pod Czerwoną Żabą - tu pije się piwo - albo w nocnym klubie Pod Różowym Wzgórkiem, w którym pija się koniak. Transfer tytułowego wnuka Szwejka, jak nazywa się Isztwanka z powodu jego gadulstwa, z gospody do klubu symbolizuje jego awans, a jest to ten rodzaj awansu, który polski odbiorca zna z Kariery Nikodema Dyzmy Tadeusza Dołęgi-Mostowicza czy Wystarczy być Jerzego Kosińskiego. Spin-doctor Puzon postanawia zrobić z Isztwanka premiera, co mu się zresztą ostatecznie udaje. Wnuk Szwejka stoi więc w rozkroku między dwoma światami: światem prostych ludzi i wyższych sfer, gospody i polityki, biedy i bogactwa, prostactwa i wyrafinowania. Zachowuje wszystkie atrybuty prymitywa - więcej: dzięki nim wygrywa wybory, chwaląc się na przykład, że jego IQ jest dwucyfrowe, przy czym zupełnie nieonieśmielony korzysta $\mathrm{z}$ luksusów, które wiążą się z jego nową rolą. Tę dwoistość, podobnie jak u Havla, symbolizuje sposób, w jaki Isztwanek pije alkohol. Zacytuję fragment sceny z klubu:

Pozoun

Miluji ústřice [...]

a jedině sem je vozí každy den čerstvé

Tomu koňaku je dvacet let

(a oba se napijí, Ištvanek koňak vypije na jedno polknutí)

$[\ldots]$

Pozoun

Víte, že to hovado

klidně vypije vanu plnou

koňaku

a jím to proteče

a nezachytí se v něm nic

Zbůhdarma

jako kdyby to bylo síto

(Balák 2019)

Rodzaj preferowanego trunku, sposób picia, ucztowania, a także oddziaływanie alkoholu na pijącego (posiadanie tzw. „mocnej głowy") służą w sztuce Baláka jako sygnały charakteryzujące bohaterów i lokujące ich w określonych środowiskach. Ponadto rytuał związany z piciem - w tym przypadku zarówno w gospodzie, jak i w nocnym klubie - ma silny ładunek teatralności: opiera się bowiem na dialogu, podstawowym budulcu dramatu, a w wymiarze teatralnym organizuje scenografię i ruch postaci.

\section{Nože a růz̆e aneb topless party Miloša Urbana}

Porzucenie swojskiego piwa na rzecz bardziej wyrafinowanych alkoholi jako wyznacznik czy symbol awansu społecznego to motyw istotny także w sztuce Nože a rǔže aneb topless party Miloša Urbana z 2005 roku. Grono szkolnych kolegów, pośród których jedni zrobili kariery, a inni pozostali w tyle, spotyka się na dorocznym ,wieczorku”. Jeden z nich przynosi szampana, co oznacza, że jego status społeczny znacząco się zmienił:

VENCA: (postaví na stůl basu piv, všimne si sektu, podívá se na Pavla, pohledem spočítá dvanáct svých lahví a poměří je s dvěma lahvemi sektu; s povytaženým obočím koukne na etiketu) Tohles přines, jo? Hm. Taky dobrý, docela. [...]

PAVEL: Cos to řek na to šampaňský? „Taky dobrý, docela?” To je Madame Cliqot, člověče! Stará „klikotka”! To pijem, když vyhráváme volby.

VENCA: Fakt? A co pijete, když prohráváte?

PAVEL: Vodku (Urban 2005, s. 11) ${ }^{2}$.

Pod wieloma względami ta scena przypomina epizod z Niewiedzy Milana Kundery, w którym emigrantka Irena przywozi na spotkanie z dawnymi czeskimi przyjaciółkami dobre wino. One jednak dają

\footnotetext{
${ }^{2}$ WICEK: Witam panów. Pawle, ten środkowy palec w oknie taksówki musimy przedyskutować (stawia na stół dwa sześciopaki piwa, wyjmuje z kieszeni komórkę i odkłada ją na tacę; dostrzega alkohol, patrzy na Pawła, wzrokiem przelicza swoich dwanaście butelek i porównuje je z dwiema butelkami szampana; ze zmarszczonym czołem przygląda się etykiecie). Ty to przyniosłeś, co? Chmm... No, całkiem dobra rzecz. $[\ldots]$

PAWEŁ: Jak ty to powiedziałeś? Całkiem dobra rzecz? Chłopie, to jest „Madame Cricot”! Stara dobra krikotka! My to pijemy, jak wygrywamy wybory!
}

WICEK: Serio? A co pijecie, jak przegrywacie?

PAWEL: Wódkę. [przekład Agata Firlej]. 
pierwszeństwo piwu, by potem dopiero sięgnąć po wino i nie docenić go. Preferowanie innego trunku oznacza tu zerwanie z dawnymi przyjaciółmi, z całą kulturą, niemożność porozumienia się emigrantki z rodakami. Podobnie funkcjonuje szampan Pawła w omawianej sztuce, do czego dochodzi jeszcze wątek polityczny (i nie chodzi tylko o podział: szampan $=$ zwycięstwo $\mathrm{w}$ wyborach, wódka = przegrana), ale o zewnętrzny znak przynależności do rządzącej, lepszej kasty, w odróżnieniu do podporządkowanej, piwnej masy.

\section{Růže pro Marketu aneb večírky revolucionářù Michala Viewegha}

W sztuce Růže pro Marketu aneb večirky revolucionářù Michala Viewegha, napisanej prawdopodobnie (o ile to nie mistyfikacja) mniej więcej w tym samym okresie, co najpopularniejsza powieść tego autora, Baječná léta pod psa, alkohol towarzyszy rewolucyjnemu - nomen omen - fermentowi. W recenzji tej sztuki Martin Kopáč pisał:

V „růžovém” časoprostoru tři večerních seancí v panelákovém obýváku někdy v prosinci 1989 se rozvíjejí v zásadě milé konverzační, někdy až vančurovsky hravé slovesné eskapády na pomezí komiky a únosné tragédie. Mezi pódiem, na kterém se narychlo stavějí kulisy nových dějin, a intimními světy, jejichž kulisy se naopak bortí, se pohybují agilní zástupci studentského stávkového výboru a trojice trochu skeptických vysokoškolských profesorů-nekomunistů. Ti všichni sice v prvním plánu společně vyhánějí z pražské filosofické fakulty symbol socrealistické literární i jazykové normalizace Soběslava Zounka (rozuměj: Vítězslava Rzounka), zároveň ale sledujeme vymítání ještě jiného druhu. Jako kdyby revoluce tyhle ambiciózní děti jedno po druhém od počátku požírala ${ }^{3}$.

Viewegh komponuje swoją sztukę z matematyczną precyzją: trzy wieczory, troje głównych bohaterów, trzy zmiany strojów, trzy parawykłady, wreszcie: trzy rodzaje alkoholu, osobny dla każdego etapu

\footnotetext{
${ }^{3}$ Kopač 2004, cyt. za: http://www.ndbrno.cz/uploads/old/pdf soubory/Tiskova _zprava_Ruze_pro_Marketu.pdf [dostęp 13.07.2017]. „Oto w »różowej« czasoprzestrzeni trzech wieczornych seansów w zwykłym mieszkaniu na blokowisku, w grudniu 1989 roku, odbywają się słowne, nieco vančurowskie w tonie eskapady na granicy tragizmu i komizmu. Między sceną, która szybko przeistacza się w kulisy nowej historii, a intymną przestrzenią, której kulisy z kolei ulegają zniszczeniu, do-
}

rewolucji. Koniak na wzmożenie rewolucyjnego zapału, szampan na rewolucyjnej fali wznoszącej i wreszcie whisky - po zwycięstwie. Kiedy zaczyna się bunt, ludzie przestają być trzeźwi. Stan upojenia towarzyszy bohaterom sztuki Viewegha każdego wieczoru z narastająca intensywnością, by osiągnąć apogeum w finale. Nienormalny czas rewolucji jest więc symbolizowany przez upojenie, a ponadto - jak w Audiencji Havla - rytuał otwierania butelki i nalewania trunków, poprzedzający zawsze quasi-wykład Hugona, rytmizuje akcję.

\section{Nahniličko Jana Krausa}

W Nahniličku Jana Krausa (2003), jednej z najbarwniejszych postaci czeskiej kultury i popkultury (aktora, pisarza, dramaturga, przedsiębiorcy, dziennikarza, konferansjera, blogera, prezentera, felietonisty, bohatera skandali itd.), troje głównych bohaterów - ofiary transformacji ustrojowej, ludzie z bocznego toru - raczy się bliżej nieokreślonym, mocnym trunkiem. Awantury o przeszłość (o to, kto się „,ześwinił", a kto miał zasady, kto zarobił na zmianie systemu, a komu się nie udało, kto był w bezpiece i kto kogo do tego namawiał) stopniowo - w miarę opróżniania butelki - zmieniają się w utwór z pogranicza brazylijskiego serialu i kina akcji. Handel bronią, mafia, narkotyki, egzotyczne kobiety, Rosjanie i Latynosi, szybki zarobek, wielka polityka, a do tego romans - te wszystkie wątki splatają się i kulminują w zupełnie szalonej i infantylnej zarazem scenie zbiorowego skakania po łóżku. Nie wiadomo do końca: czy to obraz delirium trojga pijanych bohaterów czy symbol upojnego czasu transformacji ustrojowej, kiedy w ogólnym chaosie wszystko było możliwe: i „tunelowanie”, i bogacenie się z dnia na dzień, i spektakularne porażki. Bliżej nie-

chodzi do rozmów między tróiką nieco sceptycznych profesorów-antykomunistów a parą entuzjastycznie nastawionych studentów. Co prawda wszyscy bohaterowie wspólnie wyrzucają z praskiej filologii symbol uległości wobec poprzedniego systemu, Sobiesława Zounka (aluzja do rzeczywistej osoby, Vitezslava Rzounka), ale już wkrótce okazuje się, że rewolucja pożera swoje własne, ambitne i naiwne dzieci” (przekład Agata Firlej). 
określony „mocny trunek” można interpretować symbolicznie jako tajemnicze źródło zbiorowego oszołomienia, jak pigułki Murti Binga u Czesława Miłosza. Kraus wykorzystuje wszystkie składniki kiczu, który, jak wiadomo, zyskuje na znaczeniu w okresach rozchwiania i kryzysu, składniki znane ze słynnej definicji Brocha: niedostosowanie, kumulację, synestezję, operowanie dobrze znanymi motywami, przy czym ta kiczowa kreacja wspiera atmosferę delirium, alkoholowego upojenia.

$\mathrm{W}$ analizowanych utworach alkohol w powiązaniu z ideologią, polityką i życiem społecznym występuje właściwie w trzech głównych funkcjach: jako kryterium rozstrzygające w klasyfikacji swój-obcy (przy czym znaczenie ma zarówno rodzaj pitego alkoholu, jak i sposób, w jaki się to robi); jako symbol i wyznacznik awansu ze sfery rządzonych do sfery rządzących, wreszcie: stan upojenia symbolizuje nienormalny czas rewolucji, można by rzec: karnawału rewolucji. $\mathrm{Na}$ poziomie dramaturgicznym natomiast jest to narzędzie rytmizacji, nawet swoistej mechanizacji, rodem $\mathrm{z}$ teatru absurdu, a zatem również sygnał odniesienia do systemu.

\section{Literatura}

A 1 t m a n K., 1993, Krčemné Brno, Brno.

A 1 t m a n K., 2003, Zlatá doba štamgastů pražských hospod, Brno.

B a lák L., 2019, Švejkův vnuk [maszynopis udostęniony przez agencję teatralną Dilia].

D i e $1 \mathrm{e}$ r M., H a y d e $\mathrm{B}$ B., 2001, Digesting the feast: good to eat, good to drink, good to think. An Introduction, [w:] Feasts: archeological and ethnographic perspectives on food, politics and power, red. M. Dietler, B. Hayden, Washington-London, s. 120

Dörflo vá Y., D y k ová V., 2009, Kam se v Praze chodilo za múzami, Praha.

Feasts: archeological and ethnographic perspectives on food, politics and power, 2001, red. M. Dietler, B. Hayden, Washington-London.

Food, drink and identity: cooking, eating and drinking in Europe since Middle Ages, 2001, red. P. Scholliers, Oxford.

Gri g n o n C., 2001, Commensality and Social Morphology: An Essay on Typology, [w:] Food, drink and identity: cooking, eating and drinking in Europe since Middle Ages, red. P. Scholliers, Oxford, s. 23-33.
Have l V., 2019, Audience. Online: http://klks.upce.cz/attachments/article/118/ Audience.pdf.

H a v e 1 V., 1991, Audiencja, [w:] V. Havel, Teatr, przeł. A.S. Jagodziński, Bydgoszcz.

K o p a č M., 2004, S růžemi na jeviště!, „Reflex”, 09.12.

K r a u s J., 2003, Nahniličko, [w:] Ceská divadelni hra 90. let, Praha.

Pivo a česká kultura, 2017. Online: http://www.pratelepiva.cz/svet-piva/pivo-a-pivovarnictvi/pivo-a-ceska-kultura.

U r b a n M., 2005, Nože a růže aneb topless party, Brno.

V i e w e g h M., 2004, Růže pro Markétu aneb večírky revolucionář́̆ Brno.

W ę c o w s k i M., 2011, Sympozjon czyli wspólne picie. Początki greckiej biesiady arystokratycznej (IX-VII w. p.n.e.), Warszawa. 